\title{
ISLAMIC CRIMINAL LAW IN THE MALAYSIAN FEDERAL STRUCTURE: A CONSTITUTIONAL PERSPECTIVE
}

\author{
Shamrahayu A. Aziz*
}

\begin{abstract}
States in a federal type of government are allowed a certain amount of autonomy. Under the Malaysian federal structure Islamic criminal law has been put under state jurisdiction. Despite this clear position various questions pertaining to the state jurisdiction on Islamic criminal have recently been raised. This article seeks to discuss those issues in the light of the relevant constitutional provisions and judicial decisions.
\end{abstract}

\section{INTRODUCTION}

Federal Constitution of Malaysia proclaims separation of powers between federal and state governments via its provisions in Art. 74 and the $9^{\text {th }}$ Schedule. By virtue of this separation of powers, matters concerning Islamic law are placed under the state jurisdiction. Despite this, the separation of powers between the two levels of government and the states autonomous power regarding Islamic criminal law are unclear.

* $\quad$ Assistant Professor, Ahmad Ibrahim Kulliyyah of Laws, International Islamic University Malaysia. 
This essay seeks to discuss various constitutional issues on the position of Islamic criminal law in Malaysia, which includes the limited jurisdiction of Syariah courts. It is also on the basis that the Federal Constitution, under the Malaysian federal structure, has given all the states a measure of 'independent' or 'autonomous' power to deal with Islamic law in general, or Islamic criminal law in particular, yet, punishment by Syariah courts is limited by a federal law. Before embarking on the discussion in further detail, it is relevant to have a brief overview on the Malaysian federal structure and the historical position of Islamic criminal law in the country. This is important in providing a general background to the Malaysian federal system and the position of Islamic criminal law under the Malaysian constitutional framework.

\section{MALAYSIAN FEDERALISM - A BRIEF OVERVIEW}

Federal government is a system of government made up from a number of regional areas or states where the central government, or federal government, has powers over national or important issues such as foreign policy and defence, while the individual states retain a degree of regional and local autonomy, and have power over less important issues. ${ }^{1}$ Federalism is also "the establishment of a single political system, within which, regional governments are assigned authority such that neither level of government is legally or politically subordinate to the other." 2 Thus, it is common for every federal type of government to have clear division of powers between the central and the regional states be enshrined in its Constitution. This would also ensure the retention of some autonomous powers by the state; though they have to surrender some of the powers to the federal government.

$1 \quad$ See K.C Wheare, Federal Government, New York: A Galaxy Book New York Oxford University Press, 1964 and Elazar, D.J., "Federalism,” in International Encyclopedia of the Social Sciences, New York: MacMillan \& Free Press, 1968. For a discussion on federalism in Malaysia, see for instance, Abdul Aziz Bari, Malaysian Constitution: A Critical Introduction, Kuala Lumpur: The Other Press, 2003, at 125-142.

2 Watts, R.L., New Federations: Experiments in the Commonwealth, Oxford: Clarendon Press, 1966) at 13. 
Article $1^{3}$ of the Federal Constitution establishes that Malaysia is a federal type of government. Federal system of government is not new to the Malaysian practice. It has the origin in the Malaysian history. The earliest is probably the Negeri Sembilan's arrangement of nine different districts. ${ }^{4}$ During the British administration, Federated Malay States was created in 1895, followed by the creation of Malayan Union in 1946 and later the Federation of Malaya 1948 was formed. ${ }^{5}$ The Federation of Malaya 1948 had had a strong federal government. ${ }^{6}$ On this foundation the Federation of Malaya 1957 was formulated. The Constitutional Commission stated in its report that it was to create a federal form of constitution with a "strong central government with the State and Settlements enjoying a measure of autonomy ....” Generally, this term of reference is an application of the accepted principle of federalism that the states retain a "large measure of their original

$3 \quad$ Article 1 of the Federal Constitution reads:

(1) The Federation shall be known, in Malay and in English, by the name Malaysia

(2) The States of the Federation shall be Johore, Kedah, Kelantan, Malacca, Negeri Sembilan, Pahang, Penang, Perak, Perlis, Sabah, Sarawak, Selangor and Terengganu

(3) Subject to Clause (4), the territories of each of the States mentioned in Clause (2) are the territories comprised therein immediately before Malaysia Day

(4) The territory of the State of Selangor shall exclude the Federal Territory of Kuala Lumpur established under the Constitution (Amendment) (No. 2) Act 1973 [Act A206] and the Federal Territory of Putrajaya established under the Constitution (Amendment) Act 2001 [Act A1095] and the territory of the State of Sabah shall exclude the Federal Territory of Labuan established under the Constitution (Amendment) (No. 2) Act 1984 [Act A585], and all such Federal Territories shall be territories of the Federation. Abdul Aziz Bari, Malaysian Constitution: A Critical Introduction, Kuala Lumpur: The Other Press, 2003, at 127.

5 Id., 127-128.

$6 \quad$ Ibid.

7 Federation of Malaya Constitutional Commission, 1956-1957 Report, para 3. The Report is found in Kevin YL Tan \& Thio Li-ann, Constitutional Law in Malaysia and Singapore, Singapore: Butterworths, at 937-985. 
independence." ${ }^{8}$ Thus, in order to maintain a 'measure of autonomy' or a 'measure of state independence' under the Malaysian federal structure, the Federal Constitution has clearly provided for separation of powers between the federal and the state governments. This is particularly mentioned in art. 74 and the $9^{\text {th }}$ Schedule to the Federal Constitution. However, there was no bargaining between the federal and the states concerning the distribution of powers at the time when the constitution was drafted. ${ }^{9}$ Therefore, the division of powers is not free from federal bias. ${ }^{10}$ For instance, the Constitution empowers the Parliament to legislate for States in certain cases enumerated under the State List. ${ }^{11}$ The fact that the state governments are not given any say in constitutional amendment may also be said as a form of federal bias. ${ }^{12}$ Furthermore, in the event of any inconsistencies between the state law and federal law, the latter shall prevail. ${ }^{13}$ Similar state of affairs may be seen in the position of Islamic crimal law under the Malaysian federal structure.

\section{ISLAMIC CRIMINAL LAW AND THE ADMINISTRATION OF JUSTICE IN MALAYSIA - A BRIEF HISTORICAL BACKGROUND}

This section seeks to trace the origins of the legal provisions for Islam, Islamic law and their administration. Historically, Islam came to Malaya as early as the tenth century. ${ }^{14}$ Despite that, Islamic law was

$8 \quad$ K.C Wheare, Federal Government, New York: A Galaxy Book New York Oxford University Press, 1964, at 1.

Abdul Aziz Bari, Malaysian Constitution: A Critical Introduction, Kuala Lumpur: The Other Press, 2003, at 128.

$10 \quad$ Id. at 130-135.

$11 \quad$ Federal Constitution, art. 74.

12 See The Government of the State of Kelantan $v$ The Government of the Federation of Malaya and Tunku Abdul Rahman Putra al-Haj [1963] 1 MLJ 355.

13 See art. 75 or the Federal Constitution and the decision in City Council of Georgetown $v$ The Government of the State of Penang \& Anor [1967] 1 MLJ 169.

14 This is inferred from the fact that Muslims were found in Klang as early as the tenth century. See, Institut Tadbiran Awam Negara Malaysia (INTAN), Malaysia Kita, Kuala Lumpur: INTAN, 1991, at 66. 
introduced in Malacca during the fifteenth century. ${ }^{15}$ The Batu Bersurat Terengganu, which contained a number of Islamic punishments, including the punishment for adultery and false accusation was said to come came earlier than that, i.e. in 1303. ${ }^{16}$ Laws of Malacca, which introduced all types of Islamic criminal offences and punishment, ${ }^{17}$ is an indisputable proof that Islamic criminal law was the applicable law during the Malacca Sultanates. Furthermore, it is said that Islamic criminal law was rigorously applied in Kelantan during the reign of Sultan Muhammad II. ${ }^{18}$ The application of the law flourished during the reign of Sultan Mansur, ${ }^{19}$ but declined during the reign of Sultan Muhammad IV, especially after the Anglo-Siamese treaty of $1902 .{ }^{20}$

Although there are differences of opinion among the historians on the actual period of the introduction of Islamic law in Malaya, it is safe to say that Islamic criminal law is not something new to the Malaysian legal system. Though described as 'personal law,'21 one can observe various legislation on Islamic criminal law during the British administration in the Federated Malay States. For instance, in 1885, the British introduced a law named as Muhammadan to Pray in Mosques on Friday in Perak. The Enactment prescribed punishment against Muslims who did not

For a further discussion on the issue, see, Syed Naquib al-Attas, Preliminary statement on a general theory of the Islamization of MalayIndonesia Archipelago, Kuala Lumpur: Dewan Bahasa dan Pustaka, 1969.

16 See Mahmood Zuhdi Abd. Majid, Pengantar Undang-undang Islam di Malaysia, Kuala Lumpur: Penerbit Universiti Malaya, 1997.

For detail description of offences under this law, see for instance Ahmad Ibrahim, \& Ahilemah Joned, The Malaysian Legal System, $2^{\text {nd }}$ edition, Kuala Lumpur: Dewan Bahasa dan Pustaka, 1995, at 1-8, 28-35, 43-47; Mahmood Zuhdi Ab. Majid, Bidangkuasa Jenayah Mahkamah Syariah di Malaysia, Kuala Lumpur: Dewan Bahasa dan Pustaka, 2001, esp. at 74-83.

18 Abdullah Alwi Haji Hassan, The Administration of Islamic Law in Kelantan, Kuala Lumpur: Dewan Bahasa dan Pustaka, 1996, at 5.

19 Id., at 10.

$20 \quad$ Id., at 11.

21 M.B. Hooker, (ed), Reading in Malay Adat Law, Singapore: Singapore University Press, 1970, at 85, see also, Mahmood Zuhdi Abd. Majid, Pengantar Undang-undang Islam di Malaysia, Kuala Lumpur: Penerbit Universiti Malaya, 1997, at 62. 
perform their Friday prayer in mosque. In 1894, British administration in Perak and Selangor introduced a law criminalising adultery. ${ }^{22}$ Similarly, The Muhammadan Laws Enactment 1904 which contained offences and punishments involving Muslims was introduced throughout the Federated Malay States. ${ }^{23}$ The were numerous other laws dealt with Islamic criminal law during the British administration, such as Muslim Law Enactment 1904 (Pahang), Muslim Offences Order in Council 1938 (Negeri Sembilan), Muhammadan (Offences) Enactment 1939 (Perak), Offences (by Muhammadans) Enactment 1935 (Johore), Administration of Muslim Law Enactment 1952 (Selangor), Council of Religion and Malay Custom and Kathis Courts Enactment 1953 (Kelantan), Administration of Islamic Law Enactment 1955 (Terengganu), and Muslim Courts Enactment 1953 (Kedah). ${ }^{24}$ These legislation contained matrimonial offences, sexual offences and offences relating to religious belief and faith, including apostasy and conversion to Islam. ${ }^{25}$

Regarding the administration of Islamic criminal law in the country, there were Kathis and Syariah courts administering Islamic law before the British intervention. ${ }^{26}$ The highest court of appeal was the Sultan (Ruler). Mufti (juristconsult) was appointed to advise the Ruler on Islamic matters. On top of his duty as a juristconsult, the Mufti also had judicial functions, in which he was assisted by judges of Syariah courts. ${ }^{27}$ The

22 In Perak, the law was named as Adultery by Muhammadan, Order No. 1 1894. In Selangor the law was known as The Prevention of Adultery Registration 1894.

23 For more details on this discussion, see Mahmood Zuhdi Abd. Majid, Pengantar Undang-undang Islam di Malaysia, Kuala Lumpur: Penerbit Universiti Malaya, 1997.

See Ahmad Ibrahim, Islamic Law in Malaya, Singapore: Malaysian Sociological Research Institute Ltd., 1975, at 315-317 and M.B. Hooker, Undang-undang Islam di Asia Tenggara, (Trans.), Kuala Lumpur: Dewan Bahasa dan Pustaka, 1992, at 148-197. Law in Malaya, Singapore: Malaysian Sociological Research Institute Ltd., 1975.

26 AC Miller, Islam and Malay Kingship, (1981) JMBRAS, at 46. Abdullah Alwi Haji Hassan, The Administration of Islamic Law in Kelantan, Kuala Lumpur: Dewan Bahasa dan Pustaka, 1996, at 3. 
judge in Syariah courts had the jurisdiction to try criminal cases and had the power to punish infringement of moral law. ${ }^{28}$

During the British administration in the Federated Malay States, Islamic matters were left with the Rulers. Clause (6) of Pangkor Treaty 1874 stated that the British advisor in the Malay States shall not give advise on matters pertaining to Islam and Malay custom. Similarly, the Anglo-Siamese Treaty 1902 (which is said as having similar provisions to Pangkor Treaty 1874) contained a clause prohibiting the Siamese Advisor from interfering with matters pertaining to Islamic religion and Malay customs. ${ }^{29}$ The British and Siamese neglected the Kathis Court, which caused poor administration in the Court. They also had given limited jurisdiction to Kathis Court - Court only had jurisdiction on matrimonial and personal matters only.

In the Federated Malay States, Courts Enactment was introduced in 1905. The Enactment placed the Kathis Court under the Second Class Magistrate Court. Appeal against the decision of the Kathis Court lay before the Magistrate Court. The Enactment also created Supreme Court as the highest court of appeal (not the Rulers anymore). In 1919, the Courts Enactment was introduced. It repealed the 1905 Enactment. It created two separate courts; the civil court and the Kathis Court. Section 63 of the Enactment provided that the Kathis Court shall have jurisdiction only on matters pertaining to 'Muhammadan religion, marriage and divorce, and in all other matters regulated by Muhammadan law.' Appeal from Kathis Court shall lie before the Ruler-in-Council. In 1948, Court Ordinance 1948 (No. 43 1948) was enacted by the Federal Legislative Council. This 1948 Ordinance repealed all provisions under the Court Enactment 1919, except those provisions relating to Kathis Court. The mischief that the 1948 Ordinance had created was that it omitted Kathis Court from the federal court system; that created two parallel court system. ${ }^{30}$

From these historical facts, it is perceived that that Islamic law, or Islamic criminal law in particular, was widely applied, and administered accordingly, before and even during the British intervention. History

\footnotetext{
$28 \quad$ Ibid.

$29 \quad$ Id., at 12.

30 Mohammad Imam, "Syariah/Civil Courts' Jurisdiction in Matters of Hukum Syara: A Persisiting Dichotomy” [1995] 1 CLJ lxxxi.
} 
also tells us quite clearly that Islam and Islamic law, including Islamic criminal law were exclusively placed under the Rulers’ prerogative.

\section{ISLAMIC MATTERS AND THE FEDERAL CONSTITUTION}

By virtue of art. 74 and State List of the $9^{\text {th }}$ Schedule to the Federal Constitution, matters relating to Islam are placed under the state jurisdiction. ${ }^{31}$ By these provisions one may say that states are given an amount of autonomy on matters pertaining to Islam. Mamat bin Daud's Case $^{32}$ is a classic illustration to this state of affairs.

In Mamat bin Daud's Case, the petitioners were charged with an offence under section 298A, a section introduced into Chapter XV of the Penal Code by an Amendment Act of Parliament (Act A549) in $1983 .{ }^{33}$ They were charged for doing acts likely to prejudice unity among persons professing the religion of Islam. They were alleged to have acted as unauthorised Bilal, Khatib and Imam at a Friday prayer in Terengganu without being so appointed under the Terengganu Administration of Islamic Law Enactment 1955.

The main issue in the case was constitutional validity of section 298A of the Penal Code. The petitioners contended before the Supreme Court that section 298A of the Malaysian Penal Code concerned religion in general and Islam in particular. Consequently, Parliament was incompetent to legislate on the matter and the law was contended to be void except with regard to the Federal Territories of Kuala Lumpur and

$31 \quad$ For further reading on this see for instance, Mohamed Ismail bin Mohamed Shariff, "The Legislative Jurisdiction of the Federal Parliament in Matters Involving Islamic Law” [2005] 3 MLJ cv; see also Abdul Aziz Bari, Islam dalam Perlembagaan Malaysia, Petaling Jaya: Intel Multimedia and Publication, 2005, esp. at 101-104.

$32 \quad$ Mamat bin Daud v Government of Malaysia [1988] 1 MLJ 119 (SC).

33 Section 298A of the Penal Code was amended by Amendment Act A614 on $30^{\text {th }}$ May 1985 to provide for a mandatory punishment of imprisonment of not less than two years and not more that five years. The amendment also excluded the application of sections 173A and 294 of the Criminal Procedure Code, Act 593. 
Labuan. ${ }^{34}$ The respondents on the other hand, contended that the section was a law on public order, internal security and also criminal law in accordance with art. 11(5), and items 3 and 4 of the Federal List of the $9^{\text {th }}$ Schedule to Federal Constitution that come within Parliament's legislative power.

Deciding in favour of the petitioners, the majority ${ }^{35}$ held that in "pith and substance," ${ }^{36}$ section 298A concerned religion in general and Islam in particular. Parliament has ultra vires its legislative power in enacting section 298A of the Penal Code. In other words, the majority was saying that Parliament cannot indirectly legislate on a matter in which it has no jurisdiction to legislate it directly. The dissenting judges, ${ }^{37}$ on the other hand, were of the view that the real object of section 298A is the preservation of public order. Abdoolcader SCJ said: "Although it deals with acts connected with religion, the real object of section 298A is the preservation of public order." ${ }^{38}$ In the same breath Hashim Yeop A. Sani SCJ said,” ... [I]n my view it clearly relates to the dominant aspect of

34

It is argued that the law is still valid in the Federal Territories since Parliament is the competent legislature for the Federal Territories on matters relating to Islam.

The judges that form the majority judgment are, Salleh Abas LP, Mohamad Azmi and Seah SCJJ.

The doctrine of pith and substance means: "if an enactment substantially falls within the legislative powers of a legislature expressly conferred by the Constitution, the enactment cannot be held to be invalid, merely because it incidentally encroaches on matters assigned to another legislature.” See Markandey Katju, and S K Kaushik, N S Bindra's Interpretation of Statutes, $9^{\text {th }}$ edition, New Delhi: LexisNexis Butterworths, 2002, at 1227. The doctrine evolved due to the situation that, though the Constitution divides the powers between the Federal and State legislatures, there could be overlapping area(s) between the two legislatures. For further reading of this doctrine, see Tandon, M.P. and R, Tandon, Interpretation of Statutes and Legislation, Allahabad: Allahabad Law Agency, 1982, at 120-123; Sarathi, V.P., The Interpretation of Statutes, New Delhi: Eastern Book Company, 1986, at 544-549.

The dissenting judges were Hashim Yeop A. Sani and Abdoolcader SCJJ.

Mamat bin Daud \& Ors. v Government of Malaysia [1988] 1 MLJ 119 (SC) at 127 , para F. 
public order consequent upon activities exercised on grounds of religion and is directed at ensuring the tranquil observance of all faiths...."39 According to the minority decision, the prevailing effect of section 298A was to provide a "general law" 40 restricting the right to profess and practise religion in pursuance of Article $11(5)^{41}$ of the Federal Constitution. Furthermore, the dissenting judges also referred to the provisions of art. 74(1) of the Federal Constitution. The Clause, read together with the $9^{\text {th }}$ Schedule, provides for the scope of subject matters that comes within the legislative jurisdiction of the Federal and State Legislature.

According to the dissenting judges, the wordings of art. $74(1)^{42}$ is wide and subjective, especially when it uses the phrases "with respect to.” This phrase manifests "a degree of flexibility in legislation ... without ... transgressing the parameters of the double aspect doctrine and trenching upon a forbidden field of legislative power." 43 "Once a law in pith and substance falls within a legislative entry, an incidental encroachment on an entry in another list does not affect its validity" ${ }^{44}$ and the doctrine "introduces a degree of flexibility into the otherwise rigid scheme of distribution of powers ...." ${ }^{45}$ These statements support the situation that though the Federal Constitution has expressly enumerated the areas on which the states and the federal governments could legislate, there could be overlapping area(s) where encroachment into another

$39 \quad$ Ibid., at 131, para F.

40 The phrase "general law" however, is not defined. It may be said as different from "specific law.” It can be said that "general law” refers to the law of general application; to be applicable to each and every one in the country disregard of whether they are Muslims or non-Muslims. Article 11(5) of the Federal Constitution reads: “This Article does not authorize any act contrary to any general law relating to public order, public health and morality."

Article 74(1) of the Federal Constitution provides that: "Without prejudice to any power to make laws conferred on it by any other Article, Parliament may make laws with respect to any of the matters enumerated in the Federal List or the Concurrent List (that is to say, the State or Concurrent List set out in the $9^{\text {th }}$ Schedule to the Federal Constitution).” Emphasis supplied. (SC), at 130, per Abdoolcader SCJ, para C \& D.

$44 \quad$ Ibid., at 128.

$45 \quad$ Ibid., at 129. 
jurisdiction is inevitable. The overlapping subject matter, or the subject matter encroached upon, is thus, an incidental matter, for which the law should not be invalidated. Thus, in this present issue, according to the minority, the pith and substance of the law is the preservation of public order, and religion, particularly the religion of Islam, is only an incidental matter. The minority was of the view that, the law should not be invalidated merely because Parliament has incidentally transgressed into state matter. Thus, in light of the minority decision, section 298A is a valid law that concerns the maintenance of public order, though may at the same time affect the religion of Islam.

Although one may say that there is some weight in the reasons of judgment by the dissenting judges in Mamat bin Daud's Case it seems that the position is quite clear, the majority judgment is the applicable law - Islamic matters are entirely within the state legislative power; in no circumstances the federal government or the parliament can encroach upon such matters. At all event, the law is void for Parliament lacks of jurisdiction to legislate on Islamic matter. From the "federalism" perspective, it seems that states are given a pure autonomous power to legislate on matters relating to Islam. However, this is not always true in the case of Islamic criminal law.

\section{ISLAMIC CRIMINAL LAW AND THE CONSTITUTION}

Their Lordships ${ }^{46}$ who sat as panel judges before the Supreme Court (the then country's apex court) in Che Omar Che Soh ${ }^{47}$ pronounced that, Islamic law 'was rendered isolated in a narrow confinement of the law of marriage, divorce, and inheritance only. ${ }^{\text {, }}$ In the context of the position of Islamic criminal law in Malaysia, this statement is misleading. It is evidently clear that the Constitution guarantees the states with legislative power over offences and punishments against the precepts of Islam ${ }^{49}$ - which is obviously the

\footnotetext{
$46 \quad$ The panel judges in this case were, Salleh Abas LP, Wan Suleiman, Seah, Hashim Yeop A. Sani and Syed Agil Barakbah SCJJ. Salleh Abas LP delivered the grounds of the court's decision.

$47 \quad$ Che Omar bin Che Soh v P.P. [1988] 2 MLJ 55.

$48 \quad$ Ibid., at 56.

49 Item 1 , State List, $9^{\text {th }}$ Schedule to the Federal Constitution.
} 
state power to legislate on Islamic criminal law. ${ }^{50}$ Although later decisions ${ }^{51}$ acknowledged the special and dominant status of Islam as the religion of the Federation under the Federal Constitution, they have not declared decisively the position of Islamic criminal law in the Federation. ${ }^{52}$ This is probably justified, as Islamic criminal law was not an issue in those cases.

Item 4(h) of the Federal List, $9^{\text {th }}$ Schedule to the Federal Constitution empowers Parliament to create offences in respect of any matters under the Federal List. ${ }^{53}$ In respect of matters under State List, Item 9 of the State List authorises State Legislature to create offences in respect of matters included under the State List. ${ }^{54}$ Thus, it can be said that since Islam law is a state matter, it is the states that have the powers, and jurisdiction to deal with the Islamic criminal law.

Item 1 of the State List lays down Islamic matters stipulated under the states jurisdiction. As far as Islamic criminal law is concerned, Item 1 bestows upon the State the power to deal with "Islamic law and personal and family law of persons professing the religion of Islam." This power includes states power in "the creation and punishment of offences by persons professing the religion of Islam against the precepts of that religion, except in regard to matters included in the Federal List." The state also shall create the "organisation and procedure of Syariah courts, which shall have jurisdiction only over persons professing the

50 See the discussion below.

$51 \quad$ Meor Atiqulrahman bin Ishak v Fatimah bte Sihi \& Ors. [2000] 5 MLJ 375 (HC). For a commentary of this decision see Abdul Aziz Bari, "Islam in the Federal Constitution: A commentary on the decision in Meor Atiqulrahman" [2000] 2 MLJ cxxix.

52 For a further reading on the position of Islam in the Constitution, see for instance, Abdul Aziz Bari, Islam dalam Perlembagaan, Petaling Jaya: Intel Multimedia and Publication, 2005.

$53 \quad$ Item 4(h) of the Federal List, $9^{\text {th }}$ Schedule to the Federal Constitution reads, "Civil and criminal law and procedure and the administration of justice, including - Creation of offences in respect of any of the matters included in the Federal List or dealt with by federal law;" Item 9 of the State List, $9^{\text {th }}$ Schedule to the Federal Constitution reads: "Creation of offences in respect of any of the matter included in the State List or dealt with by State law, proofs of State law and of things done thereunder, and proof of any matter for purposes of State law.” 
religion of Islam ... but shall not have jurisdiction in respect of offences except in so far as conferred by federal law...." The states also have the power in "the determination of Islamic law...."

It is submitted that the above quoted provisions are the most important features of the Constitution on the position of Islamic criminal law under the Malaysian federal structure. By reading the provisions alltogether, it is perceived that: (1) The Constitution does not provide conclusive scope to the phrase "Islamic law, personal and family law" (2) States are guaranteed of the power and jurisdiction to deal with Islamic law, personal law and family law (3) State legislatures are given the power to create criminal offences and punishments according to Islamic precepts (4) States shall create Syariah courts to deal with Islamic matters (5) States legislatures cannot create offences and punishment on matters listed under the Federal List (6) State law on offences and punishment shall govern persons professing the religion of Islam only (7) Parliament may create a law to confer jurisdiction to Syariah courts in respect of offences (8) Syariah courts shall have jurisdiction in respect of offences in so far as conferred by federal law (9) States shall have the power to determine matters concerning Islamic law.

The phrase "Islamic law and personal and family law" is not conclusively defined by the Constitution. The phrase is said to include various Islamic family law issues, which is faraway from a comprehensive character of "Islamic law." 55 In describing the phrase, Item 1 uses the word "including," instead of "is" or "shall be." Thus, the definition given to the phrase "Islamic law and personal and family law" is not conclusive; it provides an "inclusive" definition only. From Islamic perspective, it is noteworthy that the word "Islamic law" is sufficiently exhaustive to include "personal and family law." In fact, "personal and family law" is only a small piece of Islamic law. Though the meaning of the word "family law" is clearly illustrated, the meaning of the words "Islamic law" under Item 1 is unclear. The Item also does not define the scope of the "personal law". It may be said that "personal law" in Islam differs from "personal law" in civil-law and common-law systems. Under the former, "personal law" refers to "the law of indivual's nationality"56 and under the latter, it

For the contents of Islamic law, see the discussion below. 
refers to "the law of the person's domicile."57 "Personal law" in Islam may said as referring to "religious law" ordained by God. Thus, it is suggested that, "Islamic law" and "personal law" in the context of Item 1 of the $9^{\text {th }}$ Schedule have a wide connotation and should not be confined to matters under family law only. This suggestion may be supported by the fact that the phrase used in the Item is "Islamic law and personal and family law." The word "and" used in the phrase to split "Islamic law" from "personal and family law." This indicates that they are two different subjects. This argument may also be supported by the fact that Item 1 does not provide a conclusive definition to the phrase "Islamic law, personal and family law"; it only provides an "inclusive" definition to the phrase. Nevertheless, it is admitted that the provisions in Item 1 have reduced the scope of "Islamic law" as they have limited the state legislative power to matters stipulated under the State List only.

As discussed above, Mamat bin Daud's Case established that, states jurisdiction over Islamic matter is indisputable; parliament cannot in any circumstance enact law on Islamic matter; even in a situation where Islam is only an in "incidental matter"(though parliament shall legislate on Islam for the Federal Territories). As far as Islamic criminal law is concerned, the states power to legislate on the subject is granted by the Federal Constitution itself as it allows the states to create offences and punishment against the precepts of Islam. The phrase "precepts of Islam" has an extensive meaning. "Precepts" is defined as "rule of action: a commandment: a principle." 58 The word is also defined as "standard or rule of conduct; a command or principle." 59 By looking at these definitions, it is perceived that the word "precepts" covers all aspects of commandments. What is "precepts" in Islam? Islam provides comprehensive guide for every field of activity ${ }^{60}$ which are contained in

\footnotetext{
$57 \quad$ Ibid., at 1148.

58 Chambers English Dictionary, Cambridge: Chambers Cambridge, 1988, at 1148.

$59 \quad$ Black's Law Dictionary, United States of America: West Publishing Co., 1999, at 1196. See also Farid Sufian Shuaib, Powers and Jurisdiction of Syariah Court, Kuala Lumpur: Malayan Law Journal, 2003, at 127128.

60 S. Abul A' la Maududi, Islamic law and constitution, $12^{\text {th }}$ edition, Lahore: Islamic Publications (Pvt.) LTD, 1997, at 2-6.
} 
Shariah. Shariah is defined as the norms of Islam, consisting various commandments of Allah to human kind ${ }^{61}$ It commonly refers to the "commands, prohibitions, guidance and principles that God has addressed to mankind." ${ }^{2}$ Shariah consists of al-ahkam al-i 'tiqädiyyah (sanctions relating to belief), al-ahk ām al-akhlāqiyyah (sanctions relating to moral and ethics) and al-ahkām al- 'amaliyyah (sanctions relating to human relations). ${ }^{63}$ These three main components of Shariah are the basis for criminal law in Islam. ${ }^{64}$ Therefore, it could be said that the phrase "precepts

61 Al-Qurtubi, al-Jāmi ' li Ahkām al-Qur'ān, Cairo: Dar al-Kutub alMaîriyyah, 1939, vol. 16, at 10; 'Abd al-Karīm Zaydān, al-Madkhal li Dirāsat al-Syarī'ah al-Islāmiyyah, Beirut: Muassasah al-Risalah, 1999, at 38.

62 Mohammad Hashim Kamali, An Introduction to Shari 'ah, Kuala Lumpur: Ilmiah Publishers, 2006, at 12.

63 See Al-Qurțubī, al-Jāmi li Aḥkām al-Qur'ān Cairo: Dar al-Kutub alMasriyyah, 1939, vol. 16; 'Abd al-Karīm Zaydān, al-Madkhal li Dirāsat al-Syarī'ah al-Islämiyyah, Beirut: Muassasah al-Risalah, 1999; 'Abd al-Wahhāb Khallāf, 'Ilm Ușul al-Fiqh, Kuwait: Dār al-Qalam, 1972, at 32-34; Mohammad Hashim Kamali, An Introduction to Sharī'ah, Kuala Lumpur: Ilmiah Publishers, 2006; Mohamad Akram Laldin, Introduction to Shariah and Islamic Jurisprudence, Kuala Lumpur: CERT Publications, 2006.

64 Crimes in Islam are generally forbidden acts, prohibited by the law of Allāh that are punishable with hadd or ta żìr. See Abī al-Ḥasan 'Ali bin Muḥammad Ḥabīb al-Bașrī al-Baghdādī al-Mawardī, Kitāb al-Aḥkām al-Sultāniyyah, Beirut: Dār al-Fikr, 1960, at 219. Briefly, hadd means fixed punishment. They are those punishments revealed by the Holy Qur'ān (or sunnah - according to majority view). They cannot be altered or amended. Ta'zìr offences are crimes not specifically quoted in the Holy Qur'ān (or sunnah). They are punished for disobedient of Allāh's commandment. The amount of punishment is left to the discretion of the authority and differs from one crime to another depending on the type of the offence. See 'Abd al-Qādir 'Awdah, al-Tashrī' al-jinā' $\bar{l}$ alIslāmī, Beirut: Muassasah al-Risālah, 1994 (in 2 volumes); or its translation, A.Q. Oudah Shaheed (Abdul Qadir Awdah), Criminal Law of Islam, S. Zakir Aijaz (Trans.), Delhi: International Islamic Publishers, (in 4 volumes), 2000; Muhammad Abū al-Zahrah, al- 'Uqūbah, Qaherah: Dār Fikr 'Arabī, (n.d); Abī al-Hasan Ali bin Muhammad Habib al-Basri al-Baghdadi al-Mawardi, Kitāb al-ahkām al-sulțāniyyah, Beirut: Dār al-Fikr, 1960, at 219; 'Abd al-Karīm Zaydān, al- 'uqūbah fi al-Syarì'ah 
of Islam" is a wide and subjective phrase that would include every single rule, conduct, principle, commandment and teaching of Islam prescribed in the Shariah, including Islamic criminal law. The phrase should not be confined to the five basic pillars of Islam only. ${ }^{65}$ Islamic criminal law is therefore, included within the phrase "the creation and punishment of offences ... against the precepts of that religion [Islam].” Until 2003, all states, except Pahang have specific legislation on Syariah criminal offences. ${ }^{66}$ The legislation contain provisions on offences relating to aqidah, the sanctity of Islam and its institutions and decency.

Despite the extensive and comprehensive meanings of the phrase "precepts of Islam," the State legislative power becomes restrictive when it cannot create offences and punishment with "regard to matters included in the Federal List." The meaning of this provision is unclear. Thus far,

al-Islāmiyyah, Beirut: Muassasah al-Risālah, 1988; Tahir Mahmood et. al (Ed.), Criminal law in Islam and the Muslim world: A comparative perspective, New Delhi: Institute of Objective Studies, 1996.

A duly restrictive definition to the phrase "precepts of Islam" has been given in an affidavit in Nordin Salleh v Kerajaan Negeri Kelantan \& Anor [1993] 3 MLJ 344, at 384. The affidavit stated inter alia, the precepts of the Islamic religion are proclaiming the oneness of God and the Prophet Muhammad as the Messenger of Allāh; praying at five designated times, fasting during the month of Ramaḍann payment of alms and performing pilgrimage. Meanwhile, in Public Prosecutor $v$ Mohd Noor bin Jaafar [2005] 6 MLJ 745 the word “precepts” has been given a wider connotation.

$66 \quad$ Syariah Criminal Offences (Selangor) Enactment 2003; Syariah Criminal Offences (Takzir) (Terengganu) Enactment 2001; Syariah Criminal Offences (Sarawak) Ordinance, 2001; Syariah Criminal Offences (Johor) Enactment 1997; Syariah Criminal Offences (Federal Territories) Act 1997; Syariah Criminal Offences (State of Penang) Enactment 1996; Syariah Criminal Offences (Sabah) Enactment 1995; Criminal Offences in the Syarak (Perlis) Enactment 1993; Syariah Criminal (Negeri Sembilan) Enactment 1992; Crimes (Syariah) (Perak) Enactment 1992; Syariah Criminal (Malacca) Enactment 1991; Syariah Criminal Code (Kedah) Enactment 1988; Syariah Criminal Code (Kelantan) Enactment 1985. Kelantan and Kedah have two legislation on Islamic criminal law. Syariah offences in Pahang are found under the Administration of the Religion of Islam and Malay Custom of Pahang 1982 as amended by Amendment Enactment No. 7/1989. 
there is no judicial interpretation on the subject. Probably it can be said that State legislatures are not allowed create offences, for instance, regarding national security, or public order as these matters are under the Federal List. If this were the intended meaning of the provision, it becomes superfluous as it is understood that states have no jurisdiction over matters under the Federal List. Does it mean that the state legislatures can presume the power to criminalise theft, robbery, rape etc. as these offences are also part of Islamic criminal offences and they are not clearly provided for under the Federal List.

The Syariah courts, which have the jurisdiction to deal with Islamic matters, shall have jurisdiction over persons professing Islam only. This is illustrated in Abdul Rahim Bin Haji Bahaudin v Chief Qadhi, Kedah. ${ }^{67}$ The case established that the Syariah courts do not have the jurisdiction to try cases involving Ahmadi group as the group has been declared as non-Muslim by a fatwa issued by the Islamic Religious Council of Kedah. This state of affairs makes the implementation of Islamic criminal law in Malaysia not easy; for instance, Muslims and non-Muslims may possibly commit khalwat, or non-Muslims may sell liquor to Muslims, or sell food during the day of Ramadān to Muslims or propagate non-Islamic doctrines or belief among Muslims. ${ }^{68}$ If non-Muslim cannot be charged for those offences, (or even for abetment in the commission of the crime) state jurisdiction over Islamic criminal law becomes ineffective. ${ }^{69}$

Apart from the limited power of the state legislature on the subject of legislation, the Syariah courts penal jurisdiction is also limited. Item 1 of the State List provides that the Syariah courts shall have jurisdiction regarding offences in so far as conferred by federal law. In order to confer jurisdiction to Syariah courts in respect of offences, parliament has passed the Syariah Courts (Criminal Jurisdiction) Act. Federal bias is obvious on this issue. It denies the state independent or state autonomy over matters concerning Islamic criminal law.

\footnotetext{
$67 \quad \mathrm{JH}(1403 \mathrm{H}) 230$.

68 These are among the Syariah offences found under the various Syariah offences legislation.

$69 \quad$ For further reading on the issue, see Farid Sufian Shuaib, Powers and Jurisdiction of Syariah Cours in Malaysia, Kuala Lumpur: Malayan Law Journal, 2003.
} 


\section{SYARIAH COURTS (CRIMINAL JURISDICTION) ACT}

The initial name of the Syariah Courts (Criminal Jurisdiction) Act 1965 was Muslim Courts (Criminal Jurisdiction) Act. It contains a long title and preamble, and three sections. The long title and the preamble states that the Act is to "confer jurisdiction upon Courts constituted under any State law for the purpose of dealing with offences under Islamic law." The punishment that could be imposed by the Syariah courts according to the 1965 Act, was six months imprisonment or one thousand fine or a combination of both. ${ }^{70}$ In 1984, Muslim Courts (Criminal Jurisdiction) (Amendment) 1984 (Act A612) was introduced to extend the Syariah courts jurisdiction regarding punishment. By virtue of this Amendment Act, the Syariah courts jurisdiction regarding punishment was increased to the maximum of three years imprisonment or five thousand ringgit fine or six strokes or a combination of any of the punishment. In 1988, the 1965 Act was revised and renamed as the Syariah Courts (Criminal Jurisdiction) Act 1965 (Act 355). It was made applicable to all the States of Malaysia in 1989 by virtue of the Syariah Courts (Criminal Jurisdiction) (Amendment and Extension) Act.

Item 1 of the State List makes it possible for the Parliament to confer jurisdiction regarding "offences” on the Syariah courts. It states that the Syariah courts "...shall not have jurisdiction in respect of offences except in so far as conferred by federal law ....” This phrase had been used as a basis to create the Syariah Courts (Criminal Jurisdiction) Act $1965 .{ }^{71}$ Although the initial reason for the legislation of Syariah Courts (Criminal Jurisdiction) Act 1965 was to ensure uniformity regarding punishments in Syariah courts, ${ }^{72}$ from federalism point of view the Syariah Courts (Criminal Jurisdiction) Act 1965 has taken away the states autonomy over Islamic criminal law. Although the Constitution is not necessarily the main obstacle in the implementation of Islamic law in the states Syariah courts, the hurdle is found in the Syariah Courts (Criminal Jurisdiction) Act $1965 .{ }^{73}$ However, it is submitted that the Syariah Courts

\footnotetext{
$70 \quad$ Section 2 of the Muslim Courts (Criminal Jurisdiction) Act 1965.

71 Parliamentary Debate, 3 March 1965, p. 6523.

72 Ibid.

73 See Abdul Aziz Bari, Islam dalam Perlembagaan Malaysia, Petaling Jaya: Intel Multimedia and Publication, 2005, at 15.
} 
(Criminal Jurisdiction) Act 1965 is not applicable to the Syariah courts in Federal Territories. Section 1 (2) of the Act states that: the "Act shall apply to all the States of Malaysia" and Federal Territories are not "state" within the meaning of Article 1(2) of the Federal Constitution. Article 1(2) of the Federal Constitution reads: "The States of the Federation shall be Johor, Kedah, Kelantan, Malacca, Negeri Sembilan, Pahang, Penang, Perak, Perlis, Sabah, Sarawak, Selangor and Terengganu.” This Clause does not include Federal Territories as one of the States. The implication that may arise is that the Syariah courts in Federal Territories may not be subject to the Syariah Courts (Criminal Jurisdiction) Act 1965. It may also be argued that the Syariah courts in Federal Territories do not require conferment of jurisdiction as the courts are not consituted under the state law; the Syariah courts in the Federal Territories are the creation of an Act of Parliament. ${ }^{74}$ The long title and the preamble states that the Act is to "confer jurisdiction upon Courts constituted under any State law for the purpose of dealing with offences under Islamic law." Parliament thus, is not bound by the Syariah Courts (Criminal Jurisdiction) Act 1965 in the creation of punishment in respect of Syariah offences for the Federal Territories.

\section{CONCLUDING REMARKS}

Being independent states, the individual states in a federal type of government is allowed to retain a certain amount of autonomy. This concept seems to be applied by the Malaysian Federal Constitution. Some provisions in the Federal Constitution seem to uphold the separation of powers between the federal and state governments. In applying this principle, the Federal Constitution has placed Islamic matters under the states jurisdiction. This position was confirmed by the Supreme Court in Mamat bin Daud's Case. Despite that, states autonomy over Islamic matters is limited. There are situations where the federal government has taken up or limited the scope of some Islamic matters from the

$74 \quad$ See sections $40-57$ of the Administration of Islamic Law (Federal Territories) Act 1993 Act 505. See also Farid Suffian Shuaib, Powers and Jurisdiction of Syariah Courts in Malaysia, Kuala Lumpur: Malayan Law Journal, 2003, at 106. 
states. Although there is no identified reason for this state of affairs, it is particularly true in matters involving Islamic criminal law. The power of the state legislature to legislate on Islamic criminal law and the penal jurisdiction of Syariah courts' are subject to Federal law. This situation has made the states power and the Syariah courts jurisdiction over Islamic criminal law illusive. The state autonomy over matters concerning Islamic criminal law is therefore, unreal. Although the hurdle in the implementation of Islamic criminal law is not necessarily the Constitution itself, the existence of a federal law restricting the penal jurisdiction of Syariah courts makes the implementation of Islamic criminal law in Malaysia restrictive. 